TP Periodica Polytechnica Chemical Engineering

59(4), pp. 288-295, 2015

DOI: $10.3311 /$ PPch.7855

Creative Commons Attribution (i)

RESEARCH ARTICLE

\section{Drying Kinetics and Mathematical Modeling of Casuarina Equisetifolia Wood Chips at Various Temperatures}

\author{
Deepak Sridhar ${ }^{1}$, Gattumane Motappa Madhu ${ }^{2 *}$
}

Received 05 December 2014; accepted after revision 23 February 2015

\begin{abstract}
Casuarina equisetifolia wood is extensively used as fire wood and is also being used extensively in gassifiers. Drying is an important procedure which has to be carried out before the wood is burnt. Experiments on Casuarina wood chips of dimension $5.08 \mathrm{~cm} \times 5.08 \mathrm{~cm}$ with $2.54 \mathrm{~cm}$ thickness were carried out between $80^{\circ} \mathrm{C}$ to $100^{\circ} \mathrm{C}$ in a tray drier using air flow velocity of $0.5 \mathrm{~m} / \mathrm{s}$. Initial moisture content was found to be $48 \%$ on dry basis. The experimental drying curves showed only the falling rate period. Eleven thin-layer drying kinetic models were fitted with the experimental drying kinetics values and individual model constants were found. These models were compared using statistical measures like correlation coefficient, root mean square error, mean bias error and reduced chi-square to estimate the best model that would fit for the experiment. The drying rate and effective diffusion coefficient $\left(D_{\text {eff }}\right)$ were found to increase with temperature.
\end{abstract}

\section{Keywords}

Casuarina, Thin-layer drying models, Tray drier, Statistical measures, Effective diffusion coefficient

\footnotetext{
${ }^{1}$ The Department of Chemical and Environment Engineering,

The University of Arizona, Tucson-85721, USA

${ }^{2}$ Department of Chemical Engineering,

M. S. Ramaiah Institute of Technology,

Bangalore-560054, Karnataka, India

"Corresponding author, e-mail: madhugm_2000@yahoo.com
}

\section{Introduction}

Casuarina equisetifolia also known as beef wood is an evergreen tree that yields hard and dense wood and is naturally found on subtropical and tropical coastlines of Australia and many other Asian countries like Malaysia, Polynesia and Vanuatu [1]. From many decades this species has been extensively introduced in many parts of the world including India, Bangladesh, China, Middle East, Africa, America and many other places [2-4]. The colour of the heartwood varies from pale red-brown to dark red brown. Casuarina wood can be potentially used for direct combustion, gasification and many other purposes. Its wood ignites readily even when green, and ashes retain heat for long periods. Along with this, the rapid growth of tree makesthis tree known as the best firewood and also its wood produces high-quality charcoal. Calorific value of a matured Casuarina species can give about $20.20 \mathrm{MJkg}^{-1}$ [5]. This wood can be used both industrially and domestically. However, fresh wood is difficult to collect, transport and use, due to very high moisture content, low energy content and low bulk density [6, 7].

Dry wood results in enhanced efficiency, elevated combustion flame temperature, decreased gaseous emissions and reduced fuel use [8]. Drying of any wood removes the watercontent and thus its weight is reduced easing the shipping and handling costs. Apart from this there will be an increase in wood's strength properties [9].

Mathematical modelling is a method to have set of equations that can describe the system at any instant. The solution of the model must predict the process parameters based on initial conditions at a given time [10-12]. Initial moisture, morphology, dimensions, temperature, pressure, humidity, type of thermal energy used (infrared, microwave, hot air, etc) will effect the drying kinetics and final product quality [13-15]. The facts on the moisture removal process during the drying operation and fitting these information into mathematical models will be helpful for the design and the operation of the driers of both large scale and small scale and hence is important to improve the performance of the driers [16-18]. Laboratory based modelling may help to portray the thin layer drying process of Casuarina wood chips, as large scale studies are both expensive and 
time consuming $[19,20]$. Many works on drying of biomass have been carried out, most of them being on agricultural crops, fruits and vegetables. Not much literature on drying kinetics and mathematical modelling of Casuarina are available. The main aim of this work is to experimentally determine the drying rate kinetics of the wood chips, fit the experimental data into the drying mathematical models, determine the constants of each model used and to predict the best model using statistical analysis. Effective diffusion coefficient, which explains the moisture removal process were also found at different temperatures. By using this data, activation energy was calculated.

\section{Experimental}

\subsection{Materials}

Freshly felled Casuarina equisetifolia lumbers were procured from the outskirts of Bangalore region. The barks were segregated and only the fresh wood were cut into $5.08 \times 5.08 \mathrm{~cm}$ and $2.54 \mathrm{~cm}$ thick cuboids and were sealed in a polythene bag and stored in a freezer at $4^{\circ} \mathrm{C}$, until the experiments were performed.

\subsection{Experimental set-up}

Laboratory scale tray drier (UniversalLab Product Co., India) was used for the drying experiment. The dimensions of the drier were $90 \mathrm{~cm}$ (height), $60 \mathrm{~cm}$ (depth) and $60 \mathrm{~cm}$ (wide). Capacity of the drier was $12 \mathrm{~L}$ with $5 \mathrm{~kW}$ heating load. The drier consists of a fan, which blows air at a constant velocity of $0.5 \mathrm{~m} / \mathrm{s}$. Desired temperature was attained with $\pm 5^{\circ} \mathrm{C}$ variation. A mesh tray was specially fabricated with thin steel wires, with its opening size $5.08 \mathrm{~cm}$ by $5.08 \mathrm{~cm}$ separately so that the above mentioned sized wood chip would perfectly be seated on, allowing the drying to take place from all the sides. The fabricated mesh was placed in the middle row of the dryer and the wood chip was placed on it. During the drying process, the weights of the chips were measured using a electronic weighing balance; Shimadzu BL-320H, having an accuracy of $\pm 0.001 \mathrm{~g}$. Dry forceps were used while transferring wood chips from drier to weigh balance.

\subsection{Experimental procedure}

The wood chips were weighed using an electronic balance. The drying experiments were conducted at $80^{\circ} \mathrm{C}, 90^{\circ} \mathrm{C}$ and $100^{\circ} \mathrm{C}$ temperatures with $\pm 2{ }^{\circ} \mathrm{C}$ variations. The drier was preheated to the required temperature at the start, for half an hour before every experiment was conducted. The chip was weighed and then again placed in the tray drier. The weight of the wood was measured at regular intervals of one hour. Sample was picked out using dry forceps and was weighed and put back very quickly into the drier. All these weighing process was finished within 10 seconds. This process was done for eight hours and later the temperature was increased to $103^{\circ} \mathrm{C} \pm 2^{\circ} \mathrm{C}$ and left for a day to determine the initial moisture content. Moisture content (MC) and drying rates were calculated at different time and temperatures. The equation to find the moisture content on dry basis is shown in (1).
The drying rate was calculated as moisture removed per area of the substance to be dried for a given time interval is shown in Eq. (2) [21]. All experiments were conducted in three sets. The average of these values was used for the statistical examinations and determination of the effective diffusion coefficient.

$$
\begin{gathered}
\mathrm{MC}=\frac{\text { (wieght of wet wood chip }- \text { weight of dry wood chip })}{\text { weight of dry wood chip }} \\
\text { Drying rate }=\frac{\mathrm{kg} \text { moisture }}{(\text { Area })(\text { time })}
\end{gathered}
$$

\section{Mathematical Modelling of Drying Curves}

Equation (3) is used to calculate the moisture ratio (MR). Where, $M_{o}$ is initial moisture content (dry basis), $M_{e}$ is equilibrium moisture content and $\mathrm{M}_{\mathrm{t}}$ is the moisture content at a given time on the dry basis.

$$
M R=\frac{\left(\mathrm{M}_{\mathrm{t}}-\mathrm{M}_{\mathrm{e}}\right)}{\left(\mathrm{M}_{\mathrm{o}}-\mathrm{M}_{\mathrm{e}}\right)}
$$

Fluctuations in the relative humidity of the drying air due to the variations in the air flow velocity, temperature, and humid conditions can be observed. However, since the equilibrium moisture content is not high for agricultural products, the above equation is simplified to $\mathrm{MR}=\mathrm{M}_{\mathrm{t}} / \mathrm{M}_{\mathrm{o}}[22,23]$.

Mathematical models used in the current work are shown in Table 1. These thin layer models can be classified into three groups: theoretical, semi-theoretical and empirical. Theoretical models are based on diffusion equation or simultaneous heat and mass transfer and account for only internal resistance of the moisture movement to the surface. Whereas, semi-theoretical models are based on the closely estimated theoretical equation and empirical depends on the experimental data. Semi-theoretical models are only valid within a given temperature, relative humidity, airflow velocity and moisture content range for which they are developed $[24,25]$. Empirical models describe the drying curve for the conditions of the experiments but they neglect fundamentals of the drying process and their parameters have no physical meaning $[26,27]$. These two model types deem only the external resistance to moisture movement [28, 29]. Lewis, Page, Modified Page, Henderson and Pabis, Logarithmic, two term, modified Henderson and Pabis, simplified Fick's diffusion and modified Page-II were the semi-theoretical models and Wang and Singh, Thomson were the empirical models used in this paper. Regression analysis were performed and the models were chosen to be the best if the value of correlation coefficient $\left(\mathrm{R}^{2}\right)$ is high (nearer to one) and Chi-square $\left(\chi^{2}\right)$, Root Mean Square Error (RMSE), Mean Bias Error (MBE) values are minimum [24, 30]. The formulasz of the above mentioned statistical measures are shown below

$$
\mathrm{R}^{2}=\frac{\sum_{\mathrm{i}=1}^{\mathrm{N}}\left(\mathrm{MR}_{\mathrm{i}}-\mathrm{MR}_{\mathrm{pre}, \mathrm{i}}\right) \cdot \sum_{\mathrm{i}=1}^{\mathrm{N}}\left(\mathrm{MR}_{\mathrm{i}}-\mathrm{MR}_{\text {exp }, \mathrm{i}}\right)}{\sqrt{\left[\sum_{\mathrm{i}=1}^{\mathrm{N}}\left(\mathrm{MR}_{\mathrm{i}}-\mathrm{MR}_{\mathrm{pre}, \mathrm{i}}{ }^{2}\right)\right] \cdot\left[\sum_{\mathrm{i}=1}^{\mathrm{N}}\left(\mathrm{MR}_{\mathrm{i}}-\mathrm{MRexp}, \mathrm{i}\right)^{2}\right]}}
$$




$$
\begin{gathered}
\mathrm{RMSE}=\left[\frac{1}{\mathrm{~N}} \sum_{\mathrm{i}=1}^{\mathrm{N}}\left(\mathrm{MR}_{\text {pre }, \mathrm{i}}-\mathrm{MR}_{\mathrm{exp}, \mathrm{i}}\right)^{2}\right]^{1 / 2} \\
\chi^{2}=\frac{\sum_{\mathrm{i}=1}^{\mathrm{N}}\left(\mathrm{MR}_{\text {exp }, \mathrm{i}}-\mathrm{MR}_{\text {pre }, \mathrm{i}}\right)^{2}}{\mathrm{~N}-\mathrm{n}} \\
\mathrm{MBE}=\frac{1}{\mathrm{~N}} \sum_{\mathrm{i}=1}^{\mathrm{N}}\left(\mathrm{MR}_{\text {pre }, \mathrm{i}}-\mathrm{MR}_{\text {exp }, \mathrm{i}}\right)
\end{gathered}
$$

Here, $\mathrm{N}$ is the total number of observations, $\mathrm{n}$ is the number of model parameters, MR denotes the moisture ratio; $\mathrm{MR}_{\mathrm{pre}, \mathrm{i}}$ and $\mathrm{MR}_{\text {exp,i }}$ is the predicted and experimental moisture ratio at $i^{\text {th }}$ observation respectively.

\section{Results and Discussion}

\subsection{Drying characteristics of the Casuarina chips}

The initial moisture content of the wood was found to be around $48 \%$ on dry basis. Moisture content was decreased with increase in time and temperature (Fig. 1). The drying time was reduced to attain determined moisture content as the temperature is increased. This may be attributed to the increase in the water molecule energy due to an increase in the temperature and also because of a larger difference in the partial pressure of the vapor in the drying air to the vapor pressure of the moisture in the wood at higher temperatures [31, 32] which consequences in quicker evaporation of moisture from the wood chips. Similar observations may be made from Fig. 2. Constant drying rate period was not observed and all the drying was found only in the falling rate period (Fig. 3). Absence of constant rate period may be due to the absence of free surface water, therefore no surface evaporation took place at constant rate. Hence we can infer that mass transfer of the moisture during drying took place predominantly by liquid diffusion. Similar results have been obtained from other authors $[22,33,34]$. From Fig. 3, it is clear that the drying rate was found to be higher at high temperature and decreased with increase in drying time.

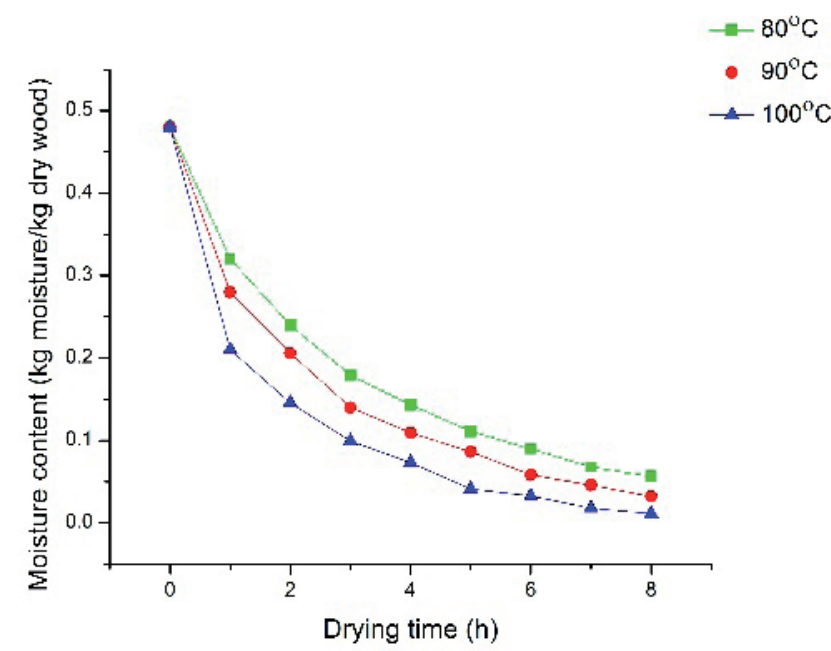

Fig. 1 Variation of moisture content with time for different temperatures

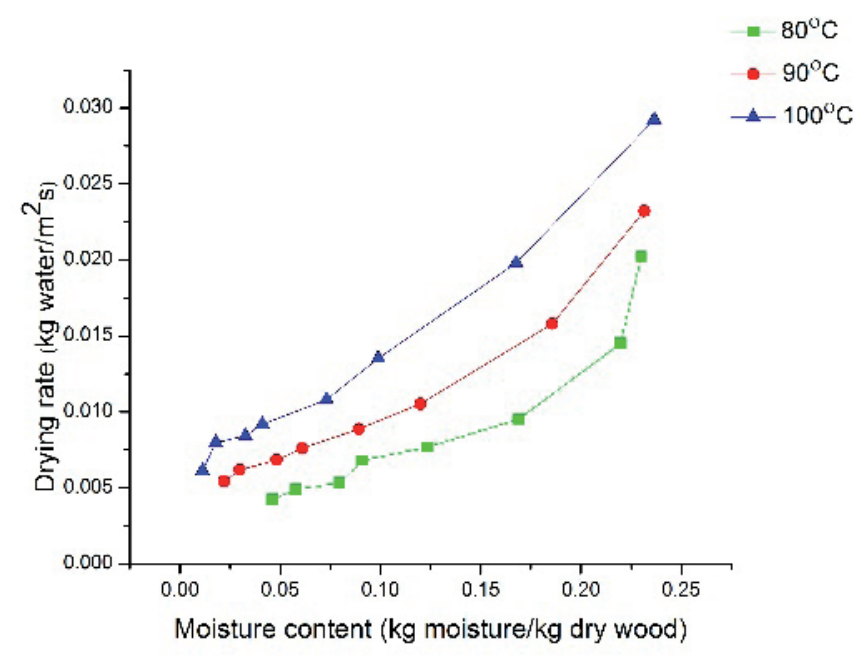

\begin{tabular}{|c|c|c|c|}
\hline Model no. & Model name & Model equation & Name of the model \\
\hline 1 & Lewis & $\mathrm{MR}=\mathrm{e}^{-\mathrm{kt}}$ & Lewis (1921) \\
\hline 2 & Page & $\mathrm{MR}=\mathrm{e}^{-\mathrm{kt} \mathrm{t}^{\mathrm{n}}}$ & Page (1949) \\
\hline 3 & Modified Page & $\mathrm{MR}=\mathrm{e}^{-(\mathrm{kt})^{\mathrm{n}}}$ & Wang and Singh (1978) \\
\hline 4 & Henderson and Pabis & $\mathrm{MR}=\mathrm{ae}^{-\mathrm{kt}}$ & Henderson and Pabis (1969) \\
\hline 5 & Logarithmic & $\mathrm{MR}=\mathrm{ae}^{-\mathrm{kt}}+\mathrm{c}$ & Yagcioglu et al. (1999) \\
\hline 6 & Two term & $\mathrm{MR}=a \mathrm{e}^{-\mathrm{k}_{\mathrm{o}} \mathrm{t}}+\mathrm{be}^{-\mathrm{k}_{1} \mathrm{t}}$ & Henderson (1974) \\
\hline 7 & Wang and Singh & $\mathrm{MR}=1+\mathrm{at}+\mathrm{bt}^{2}$ & Wang and Singh (1978) \\
\hline 8 & Thomson & $\mathrm{t}=\mathrm{a} \cdot \ln \mathrm{MR}+\mathrm{b} \cdot[\ln (\mathrm{MR})]^{2}$ & Thompson et al. (1968) \\
\hline 9 & Modified Henderson and Pabis & $\mathrm{MR}=a \mathrm{e}^{-\mathrm{kt}}+\mathrm{be}^{-\mathrm{gt}}+\mathrm{ce}^{-\mathrm{ht}}$ & Karathanos (1999) \\
\hline 10 & Simplified Fick’s Diffusion & $\mathrm{MR}=a \mathrm{e}^{\frac{-\mathrm{ct}}{\mathrm{L}^{2}}}$ & Diamente and Munro (1991) \\
\hline 11 & Modified Page-II & $\mathrm{MR}=\mathrm{e}^{-\mathrm{k}\left(\frac{\mathrm{t}}{\mathrm{L}^{2}}\right)^{3}}$ & Diamente and Munro (1993) \\
\hline
\end{tabular}

Fig. 2 Variation of drying rate with moisture content at different temperatures

Table 1 Various mathematical models used 


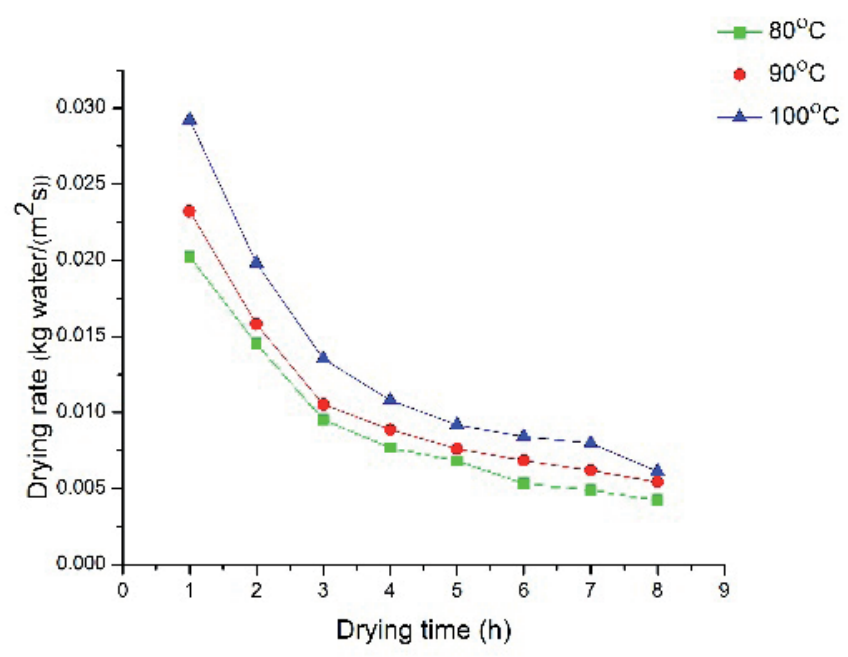

Fig. 3 Variation of drying rate with drying time at different temperatures

\subsection{Mathematical modeling}

The experimental data of the drying process were fit into the mathematical models as listed in Table 1, which are frequently used in the drying of biomass feed stock [29, 35-41]. These were fitted to the experimental drying facts to find the constants of each model. The closeness of the relation of the model was determined by the correlation coefficient $\left(\mathrm{R}^{2}\right) \cdot \chi^{2}$ and RMSE shows the deviation between the experimental and predicted values. In particular, lower the $\chi^{2}$ value; better the fit and lower RMSE shows good short term performance. MBE provides information on the long term performance of the correlations, helping for the comparisons of the actual deviation between experimental and predicted values $[42,43]$.

Various constants and the regression analysis data calculated for eleven models at various temperatures $(\mathrm{T})$ are shown in Table 2. All the models used were found to predict drying to a good extent, however modified Henderson and Pabis, and Logarithmic model was found to predict the drying very well as it showed $\mathrm{R}^{2}$ values nearly approaching to one, $\chi^{2}$ and RMSE values almost approach zero. Fig. 4 and Fig. 5, shows the plot of predicted and experimental moisture ratio to illustrate the very good performance of the modified Henderson and Pabis model and the logarithmic model respectively. The performance of the logarithmic model and modified Henderson and Pabis model showed a straight line with $\mathrm{R}^{2} 0.9958$ and 0.9928 respectively, showing that these models are highly suitable for predicting the drying characteristics of Casuarina wood chips in the conducted experimental range of this study.

\subsection{Effective diffusion coefficient $\left(D_{\text {eff }}\right)$ and activation energy}

Fick's second law equation is used to determine the diffusivity of water in the falling rate period, assuming diffusivity to be the sole physical mechanism responsible for the transfer of water to the wood surface [44-46]. In other words, during the falling rate period only the internal resistance regulates the mass transfer of

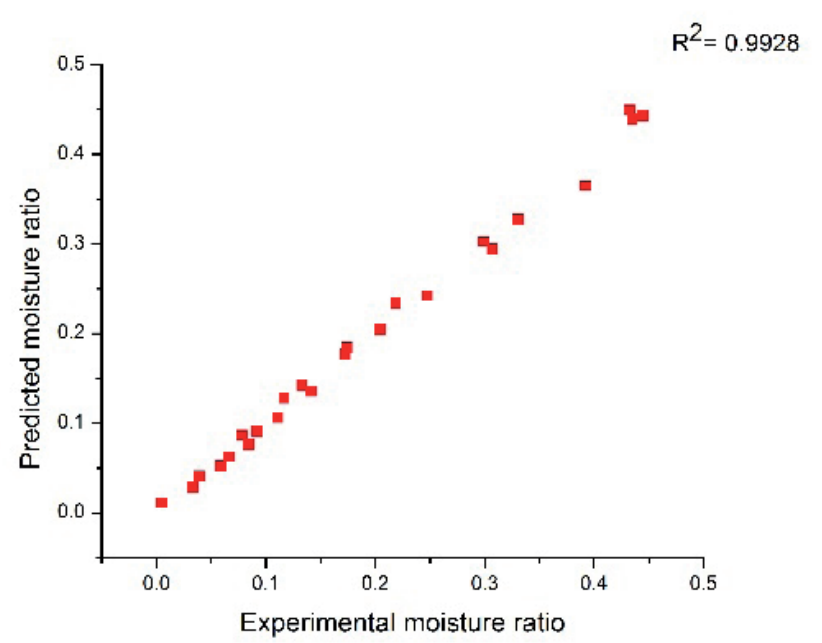

Fig. 4 Experimental versus predicted moisture ratio (Modified Henderson and Pabis model) for different drying temperatures

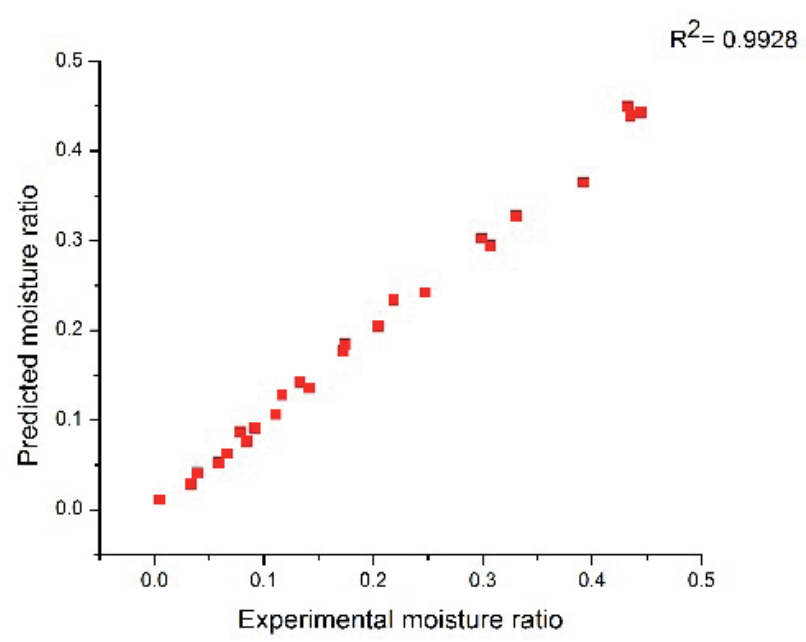

Fig. 5 Experimental versus predicted moisture ratio (Logarithmic model) for different drying temperatures

the moisture. Relation between the moisture ratio and the effective diffusion coefficient was given by Crank (1975) [47] and this could be used for slab geometry by making an assumption that initial moisture is uniformly distributed in the sample. This relation was reduced to Eq. (8) for long term drying [12, 48-50]. In order to use (8), it is assumed that the wood chip is homogeneous, isotropic, drying occurs only in the falling rate period, mass transfer through the wood is controlled by liquid diffusion and any effect caused by shrinkage is negligible [40, 51].

$$
M R=\frac{8}{\pi^{2}} \exp \left[\frac{-\pi^{2} D_{e f f} t}{4 L^{2}}\right]
$$

Where $\mathrm{L}$ is the half thickness of the wood chip (m), $D_{\text {eff }}$ is the effective diffusion coefficient in $\mathrm{m}^{2} / \mathrm{s}$ and $\mathrm{t}$ is the drying time in seconds. By plotting Ln MR versus drying time, $D_{\text {eff }}$ can be found from the slope of the line (Fig. 6). $D_{\text {eff }}$ increased with increase in temperature from $4.43 \times 10^{-9} \mathrm{~m}^{2} /$ sto $10.15 \times 10^{-9} \mathrm{~m}^{2} / \mathrm{s}$ as the movement of water to the surface of the wood chip increases, the values are tabulated in Table 3 . 
Table 2 Statistical analysis coefficients of various models used

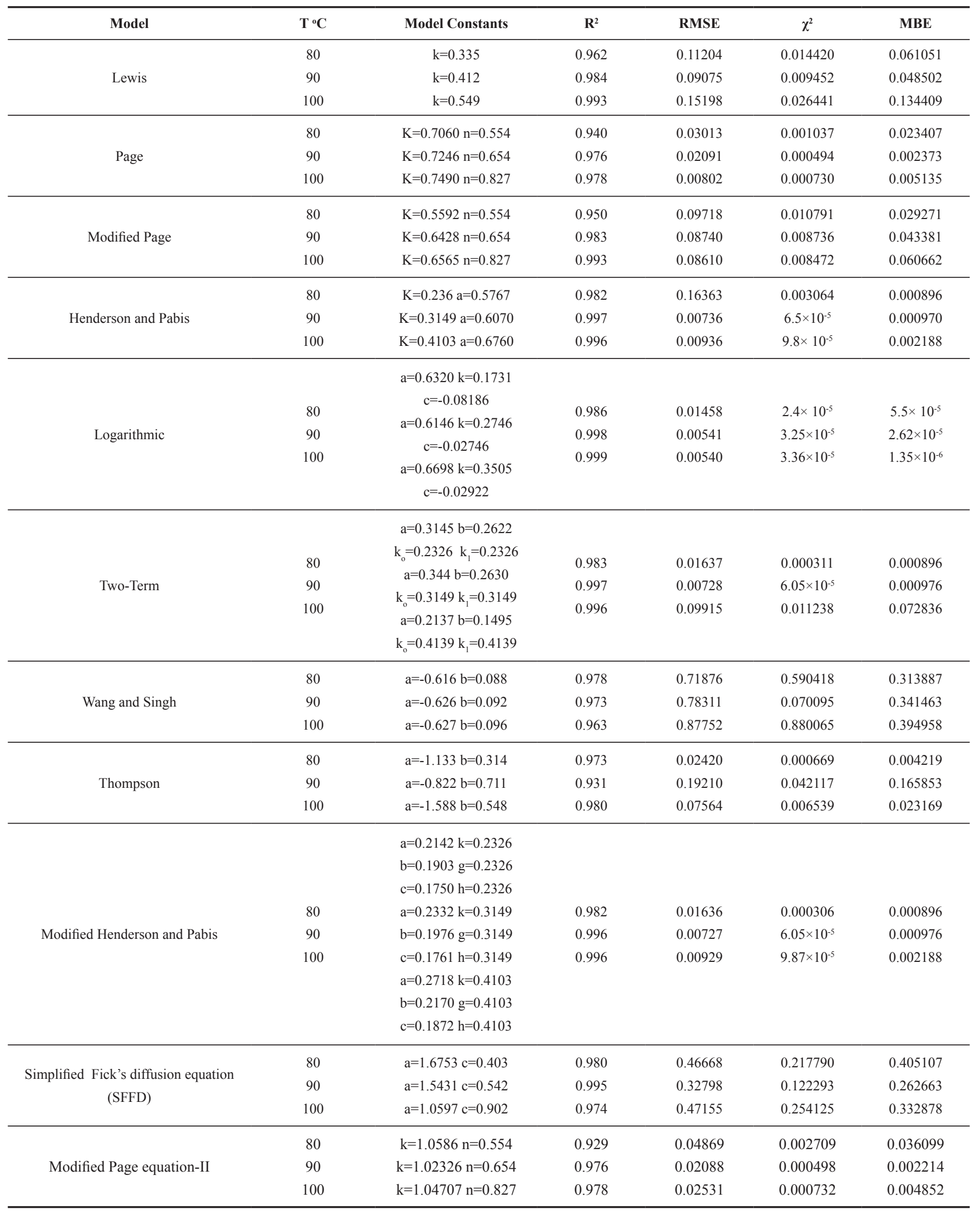




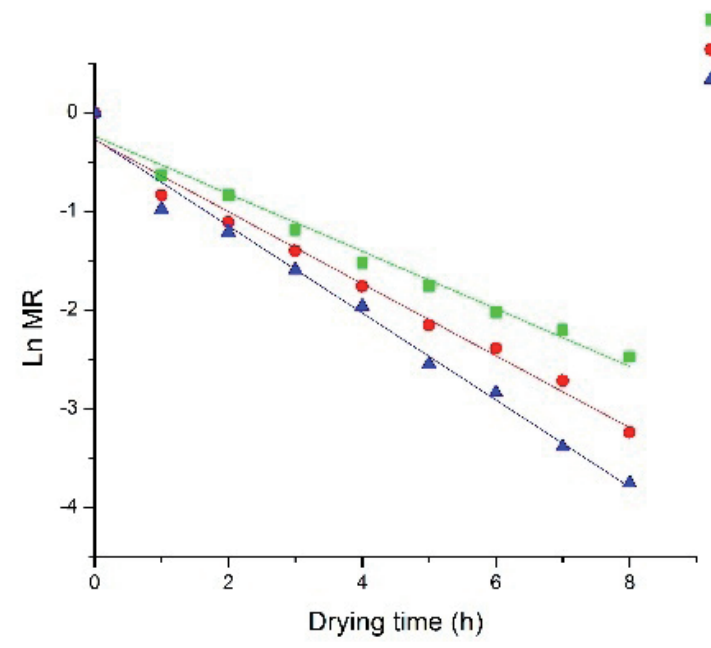

Fig. 6 Plot of $\ln$ MR vs drying time at various temperatures.

The activation energy was estimated using the Arrhenius equation shown in Eq. (9) [51-54]. Ln $\mathrm{D}_{\text {eff }}$ versus reciprocal of absolute drying air temperature $\left(\mathrm{T}_{\mathrm{a}}\right)$ were plotted (Fig. 7) and from the slope of the line, activation energy $(\mathrm{kJ} / \mathrm{mol})$ and from the intercept pre-exponential factor was found.

$$
D_{\text {eff }}=D_{o} \exp \left[\frac{-E_{a}}{R T_{a}}\right]
$$

Table 3 Effective diffusivities at different temperatures

\begin{tabular}{ccc}
\hline $\begin{array}{c}\text { Drying air } \\
\text { Temperature }\left({ }^{\circ} \mathbf{C}\right)\end{array}$ & $\begin{array}{c}\text { Effective diffusion coefficient } \\
\left(\mathbf{m}^{2} / \mathbf{s}\right)\end{array}$ & $\mathbf{R}^{\mathbf{2}}$ \\
\hline 80 & $4.43 \times 10^{-9}$ & 0.992 \\
90 & $6.12 \times 10^{-9}$ & 0.993 \\
100 & $10.15 \times 10^{-9}$ & 0.996 \\
\hline
\end{tabular}

In the above equation $\mathrm{D}_{\text {eff }}$ is the effective diffusion coefficient in $\mathrm{m}^{2} / \mathrm{s}, \mathrm{D}_{\mathrm{o}}$ is the pre-exponential factor of the Arrhenius equation in $\mathrm{m}^{2} / \mathrm{s}, \mathrm{E}_{\mathrm{a}}$ is the activation energy in $\mathrm{kJ} / \mathrm{molK}$ and $\mathrm{T}_{\mathrm{a}}$ is absolute drying air temperature in K. Activation Energy was found to be $45.27 \mathrm{~kJ} / \mathrm{molK}$ and the pre-exponential factor was determined as $2.15 \times 10^{-2} \mathrm{~m}^{2} / \mathrm{s}$.

\section{Conclusions}

Initial moisture content of the Casuarina wood chips was found to be approximately $48 \%$ on dry basis. Constant rate drying period was not observed. The results showed that drying curves were greatly influenced by the drying temperature. The drying rate was found to increase with drying temperature. Logarithmic and Modified Henderson and Pabis models predicted the drying rate in a best manner among the models used in the temperature rage $80^{\circ} \mathrm{C}$ to $100^{\circ} \mathrm{C}$. The effective diffusion coefficient increased from $4.43 \times 10^{-9} \mathrm{~m}^{2} /$ sto $10.15 \times 10^{-9} \mathrm{~m}^{2} / \mathrm{s}$ as the temperature increased from $80^{\circ} \mathrm{C}$ to $100^{\circ} \mathrm{C}$. The activation energy for the water diffusion was found to be $45.27 \mathrm{~kJ} / \mathrm{mol} \mathrm{K}$ and pre-exponential factor was determined to be $2.15 \times 10^{-2} \mathrm{~m}^{2} / \mathrm{s}$.

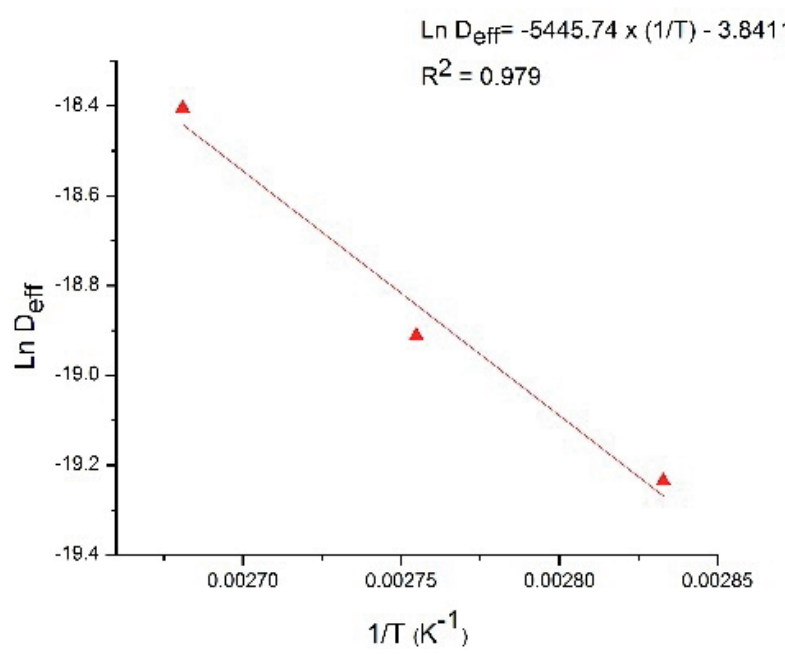

Fig. 7 Relation between the reciprocal of absolute temperature and effective diffusion coefficient

\section{References}

[1] Pinyopusarerk, K., Williams, E. R. "Range-wide provenance variation in growth and morphological characteristics of Casuarina equisetifolia grown in Northern Australia." Forest Ecology and Management. 134. pp. 219-232. 2000. DOI: 10.1016/S0378-1127(99)00260-1

[2] Rodgers, J. C., Ambinakudige, S. "Distribution Patterns of Invasive Casuarinas (Casuarina equisetifolia L.) Within Beach Environments on San Salvador Island, the Bahamas." Natural Areas Journal. 32 (4). pp. $386-$ 390. 2012. DOI: $10.3375 / 043.032 .0406$

[3] Tomar, O. S., Gupta, R. K. "Relative Performance of Some Accessions of Casuarina spp. and Silvicultural Practices on Saline Waterlogged Soils in Semiarid Conditions." Arid Land Research and Management. 16 (2). pp. 177-184. 2002. DOI: 10.1080/153249802317304468

[4] Wheeler, G. S., Taylor, G. S., Gaskin, J. F., Purcell, M. F. "Ecology and Management of Sheoak (Casuarina spp.), an Invader of Coastal Florida, U.S.A.." Journal of Coastal Research. pp. 485-492. 2010. DOI: 10.2112/JCOASTRES-D-09-00110.1

[5] Kumar, R., Pandey, K. K., Chandrashekar, N., Mohan, S. "Study of age and height wise variability on calorific value and other fuel properties of Eucalyptus hybrid, Acacia auriculaeformis and Casuarina equisetifolia." Biomass and Bioenergy. 35 (3). pp. 1339-1344. 2011.

DOI: 10.1016/j.biombioe.2010.12.031

[6] Moreno, R., Antolín, G., Reyes, A., Alvarez, P. "Drying Characteristics of Forest Biomass Particles of Pinus radiata." Biosystems Engineering. 88 (1). p. 105-115. 2004. DOI: 10.1016/j.biosystemseng. 2004.02.005

[7] Mani, S., Sokhansanj, S., Bi, X., Turhollow, A. "Economics of producing fuel pellets from biomass." Applied Engineering in Agriculture. 22 (3). 421. 2006. DOI: $10.13031 / 2013.20447$

[8] Tillman, D. A. "Biomass cofiring: the technology, the experience, the combustion consequences." Biomass and Bioenergy. 19 (6). pp. 365-384. 2000. DOI: 10.1016/S0961-9534(00)00049-0

[9] Bergman, R. "Drying and control of moisture content and dimensional changes." Wood handbook —wood as an engineering material. General Technical Report FPL-GTR-113. Madison, WI: US Department of Agriculture, Forest Service, Forest Products Laboratory. pp. 11-13. 2010.

[10] Bartzanas, T., Bochtis, D. D., Sørensen, C. G., Sapounas, A. A., Green, O. "A numerical modelling approach for biomass field drying." Biosystems Engineering. 106 (4). pp. 458-469. 2010.

DOI: 10.1016/j.biosystemseng.2010.05.010 
[11] Kumar, N., Sarkar, B. C., Sharma, H. K. "Mathematical modelling of thin layer hot air drying of carrot pomace." Journal of food science and technology. 49 (1). pp. 33-41. 2012.

[12] Dissa, A. O., Bathiebo, D. J., Desmorieux, H., Coulibaly, O., Koulidiati, J. "Experimental characterisation and modelling of thin layer direct solar drying of Amelie and Brooks mangoes." Energy. 36 (5). pp. 2517-2527. 2011. DOI: 10.1016/j.energy.2011.01.044

[13] Rousset, P., Figueiredo, C., De Souza, M., Quirino, W. "Pressure effect on the quality of eucalyptus wood charcoal for the steel industry: A statistical analysis approach." Fuel processing technology. 92 (10). pp. 1890-1897. 2011. DOI: 10.1016/j.fuproc.2011.05.005

[14] Taghiyari, H. R., Habibzade, S., Miri Tari, S. M. "Effects of wood drying schedules on fluid flow in Paulownia wood." Drying Technology. 32 (1). pp. 89-95. 2014. DOI: 10.1080/07373937.2013.813855

[15] Korkut, D. S., Hiziroglu, S., Aytin, A. "Effect of heat treatment on surface characteristics of wild cherry wood." Bioresource. 8 (2). pp. 1582-1590. 2013. DOI: 10.15376/biores.8.2.1582-1590

[16] Blazquez, M. R. B. "Modeling and optimization of a dryer." Drying Technology. 4 (1). pp. 45-66. 1986. DOI: 10.1080/07373938608916310

[17] Mustayen, A. G. M. B., Mekhilef, S., Saidur, R. "Performance study of different solar dryers: A review." Renewable and Sustainable Energy Reviews. 34. pp. 463-470. 2014. DOI: 10.1016/j.rser.2014.03.020

[18] VijayaVenkataRaman, S., Iniyan, S., Goic, R. "A review of solar drying technologies." Renewable and Sustainable Energy Reviews. 16 (5). pp. 2652-2670. 2012. DOI: 10.1016/j.rser.2012.01.007

[19] De Fusco, L., Jeanmart, H., Blondeau, J. (n.d.). "A modelling approach for the assessment of an air-dryer economic feasibility for small-scale biomass steam boilers." Fuel Processing Technology. 2015. DOI: 10.1016/j.fuproc.2015.01.043

[20] Basu, P., Sadhukhan, A. K., Gupta, P., Rao, S., Dhungana, A., Acharya, B. "An experimental and theoretical investigation on torrefaction of a large wet wood particle." Bioresource Technology. 159 (0). pp. 215-222. 2014. DOI: 10.1016/j.biortech.2014.02.105

[21] Treybal, R. E., Treybal Robert, E. "Mass-transfer operations." Vol. 3. New York: McGraw-Hill.

[22] Schössler, K., Jäger, H., Knorr, D. "Effect of continuous and intermittent ultrasound on drying time and effective diffusivity during convective drying of apple and red bell pepper." Journal of Food Engineering. 108 (1). pp. 103-110. 2012. DOI: 10.1016/j.jfoodeng.2011.07.018

[23] Meziane, S. "Drying kinetics of olive pomace in a fluidized bed dryer." Energy Conversion and Management. 52 (3). pp. 1644-1649. 2011. DOI: 10.1016/j.enconman.2010.10.027

[24] Akpinar, E. K. "Drying of mint leaves in a solar dryer and under open sun: Modelling, performance analyses." Energy Conversion and Management. 51 (12). pp. 2407-2418. 2010. DOI: 10.1016/j.enconman.2010.05.005

[25] Kaleta, A., Górnicki, K., Winiczenko, R., Chojnacka, A. "Evaluation of drying models of apple (var. Ligol) dried in a fluidized bed dryer." Energy Conversion and Management. 67 (0). pp. 179-185. 2013. DOI: 10.1016/j.enconman.2012.11.011

[26] Santos, G. T., Fortes, M., Martins, J. H., Monteiro, P. M. de B. "Convective Drying Analysis of a Single Wheat Kernel Based on an Irreversible Thermodynamics Model." Drying Technology. 31 (16). pp. 1979-1993. 2013. DOI: $10.1080 / 07373937.2013 .805417$

[27] Özdemir, M., Onur Devres, Y. "The thin layer drying characteristics of hazelnuts during roasting." Journal of Food Engineering. 42 (4). pp. 225-233. 1999. DOI: 10.1016/S0260-8774(99)00126-0

[28] Midilli, A., Kucuk, H. "Mathematical modeling of thin layer drying of pistachio by using solar energy." Energy Conversion and Management. 44 (7). pp. 1111-1122. 2003. DOI: 10.1016/S0196-8904(02)00099-7
[29] Kucuk, H., Midilli, A., Kilic, A., Dincer, I. "A Review on Thin-Layer Drying-Curve Equations." Drying Technology. 32 (7). pp. 757-773. 2014. DOI: 10.1080/07373937.2013.873047

[30] Tunde-Akintunde, T. Y. "Mathematical modeling of sun and solar drying of chilli pepper." Renewable Energy. 36 (8). pp. 2139-2145. 2011. DOI: 10.1016/j.renene.2011.01.017

[31] Motevali, A., Minaei, S., Khoshtagaza, M. H. "Evaluation of energy consumption in different drying methods." Energy Conversion and Management. 52 (2). pp. 1192-1199. 2011. DOI: 10.1016/j.enconman.2010.09.014

[32] Meziane, S., Mesbahi, N. "Determination of moisture diffusivity and activation energy in thin layer drying of olive pomace." International Journal of Food Engineering. 8 (3). 2012. DOI: 10.1515/1556-3758.2648

[33] Vijayaraj, B., Saravanan, R., Renganarayanan, S. "Studies on thin layer drying of bagasse." International Journal of Energy Research. 31 (4). pp. 422-437. 2007. DOI: 10.1002/er.1237

[34] Perea-Flores, M. J., Garibay-Febles, V., Chanona-Pérez, J. J., CalderónDomínguez, G., Méndez-Méndez, J. V, Palacios-González, E., GutiérrezLópez, G. F. "Mathematical modelling of castor oil seeds (Ricinus communis) drying kinetics in fluidized bed at high temperatures." Industrial Crops and Products. 38 (0). pp. 64-71. 2012.

DOI: 10.1016/j.indcrop.2012.01.008

[35] Sobukola, O. P., Olatunde, S. O. "Effect of salting techniques on salt uptake and drying kinetics of African catfish (Clarias gariepinus)." Food and Bioproducts Processing. 89 (3). pp. 170-177. 2011.

DOI: $10.1016 /$ j.fbp.2010.06.002

[36] Shen, F., Peng, L., Zhang, Y., Wu, J., Zhang, X., Yang, G., Peng, H., Qi, H., Deng, S. "Thin-layer drying kinetics and quality changes of sweet sorghum stalk for ethanol production as affected by drying temperature."Industrial Crops and Products. 34 (3). pp. 1588-1594. 2011.

DOI: 10.1016/j.indcrop.2011.05.027

[37] Duc, L. A., Han, J. W., Keum, D. H. "Thin layer drying characteristics of rapeseed (Brassica napus L.)." Journal of Stored Products Research. 47 (1). pp. 32-38. 2011. DOI: 10.1016/j.jspr.2010.05.006

[38] Mazutti, M. A., Zabot, G., Boni, G., Skovronski, A., de Oliveira, D., Di Luccio, M., Oliveira, J. V., Rodrigues, M. I., Treichel, H., Maugeri, F. "Mathematical modeling of thin-layer drying of fermented and non-fermented sugarcane bagasse." Biomass and Bioenergy. 34 (5). pp. 780-786. 2010. DOI: 10.1016/j.biombioe.2010.01.021

[39] Erbay, Z., Icier, F. "A Review of Thin Layer Drying of Foods: Theory, Modeling, and Experimental Results." Critical Reviews in Food Science and Nutrition. 50 (5). pp. 441-464. 2010. DOI: 10.1080/10408390802437063

[40] Evin, D. "Thin layer drying kinetics of Gundelia tournefortii L." Food and Bioproducts Processing. 90 (2). pp. 323-332. 2012. DOI: 10.1016/j.fbp.2011.07.002

[41] Doymaz, I. "Drying Of Potato Slices: Effect Of Pretreatments and Mathematical Modeling." Journal of Food Processing and Preservation. 36. pp. 310-319. 2012. DOI: 10.1111/j.1745-4549.2011.00594.x

[42] Chowdhury, M. M. I., Bala, B. K., Haque, M. A. "Mathematical modeling of thin-layer drying of jackfruit leather." Journal of Food Processing and Preservation. 35 (6). pp. 797-805. 2011. DOI: $10.1111 / \mathrm{j} .1745-4549.2011 .00531 . \mathrm{x}$

[43] Gunhan, T., Demir, V., Hancioglu, E., Hepbasli, A. "Mathematical modelling of drying of bay leaves." Energy Conversion and Management. 46 (11). pp. 1667-1679. 2005. DOI:_10.1016/j.enconman.2004.10.001

[44] Doymaz, I. "Suitability of Thin-Layer Drying Models for Infrared Drying of Peach Slices." Journal of Food Processing and Preservation. 38 (6). pp. 2232-2239. 2014. DOI: 10.1111/jfpp.12277 
[45] Acar, B., Sadikoglu, H., Doymaz, I. "Freeze-drying Kinetics and Diffusion Modeling of Saffron (Crocus sativus L.)." Journal of Food Processing and Preservation. 2014. DOI: 10.1111/jfpp.12214

[46] Shi, Q., Zheng, Y., Zhao, Y. "Mathematical modeling on thin-layer heat pump drying of yacon (Smallanthus sonchifolius) slices." Energy Conversion and Management. 71 (0). pp. 208-216. 2013.

DOI: $10.1016 /$ j.enconman.2013.03.032

[47] Crank, J. "The mathematics of diffusion." Vol. 2. Oxford: Clarendon Press.

[48] Toğrul, H. "Simple modeling of infrared drying of fresh apple slices." Journal of Food Engineering. 71. pp. 311-323. 2005. DOI: 10.1016/j.jfoodeng.2005.03.031

[49] Taheri-garavand, A., Rafiee, S., Keyhani, A. "Effective Moisture Diffusivity and Activation Energy of Tomato in Thin Layer Dryer during Hot Air Drying." International Transaction Journal of Engineering, Management, \& Applied Sciences \& Technologies. 2 (2). pp. 239-248. 2011. Available from: http://TuEngr.com/V02/239-248.pdf

[50] Doymaz, I. "Thin-layer drying behaviour of mint leaves." Journal of Food Engineering. 74. pp. 370-375. 2006.

DOI: 10.1016/j.jfoodeng.2005.03.009
[51] Doymaz, I. "Air-drying characteristics, effective moisture diffusivity and activation energy of grape leaves." Journal of Food Processing and Preservation. 36 (2). pp. 161-168. 2012.

DOI: $10.1111 / \mathrm{j} .1745-4549.2011 .00557 . x$

[52] Thorat, I. D., Mohapatra, D., Sutar, R. F., Kapdi, S. S., Jagtap, D. D. "Mathematical modeling and experimental study on thin-layer vacuum drying of ginger (Zingiber officinale R.) slices." Food and Bioprocess Technology. 5 (4). pp. 1379-1383. 2012. DOI: 10.1007/s11947-010-0429-y

[53] Demiray, E., Tulek, Y. "Thin-layer drying of tomato (Lycopersicum esculentum Mill. cv. Rio Grande) slices in a convective hot air dryer." Heat and Mass Transfer. 48 (5). pp. 841-847. 2012.

DOI: $10.1007 / \mathrm{s} 00231-011-0942-1$

[54] Sadin, R., Chegini, G.-R., Sadin, H. "The effect of temperature and slice thickness on drying kinetics tomato in the infrared dryer." Heat and Mass Transfer. 50 (4). pp. 501-507. 2014. DOI: 10.1007/s00231-013-1255-3 